\title{
Assessment of Ametropia in School Children Among Urban Areas of District Etawah: An Observational Study
}

\author{
Gaurav Dubey ${ }^{1 *}$, Swati Tomar ${ }^{2}$, Kamal Pant $^{3}$, Sandeep Tripathi ${ }^{4}$ and Deepak Gupta ${ }^{5}$ \\ ${ }^{1}$ Department of Ophthalmology/Optometry, Nims University Rajasthan, Jaipur, India \\ ${ }^{2}$ Department of Ophthalmology, Nims University Rajasthan, Jaipur, India \\ ${ }^{3}$ Department of Optometry, FPS, UPUMS Saifai Etawah, U.P. India \\ ${ }^{4}$ Nims University Rajasthan, Jaipur, India \\ ${ }^{5}$ Department of Optometry, Nims University Rajasthan, Jaipur, India \\ Corresponding author email: gauravopto25@gmail.com
}

\begin{abstract}
The purpose of this study was to determine the prevalence of refractive error among senior secondary school students inurban communities at district Etawah. A community-based cross-sectional study was done by randomly selected senior secondary school children from (9th-12th) standard of urban areas of district Etawah UP with the institutional ethical permission-NIMSUNI/IEC/2019/ $\mathrm{PhD} / 137$. Informed and written Consent was obtained from the secondary school where the data is collected. All tests were given in front of a teacher during school hours on weekdays (Monday-Saturday). Male and female students from 9th to 12th grades present on the day of screening were chosen for the eye examination. Participants with dry eye, accommodative problems, amblyopia, squint, or other organic defects were excluded from the study. Refractive errors (myopia) were more common in metropolitan schoolchildren. Refractive error was more common in urban school children aged 15 and under (especially females). Myopia was determined to be the most prevalent refractive error, followed by astigmatism and hyperopia. Preschool and school screenings should be conducted to detect refractive problems early. Furthermore, schoolchildren and their parents should be taught about refractive errors. The ocular complaints were expressed as mean and standard deviation. The type of refractive errorswas scrutinized to determine the statistical difference among the group at $95 \%$ confidence level $(\mathrm{P}<0.05)$ using the chi-square test.
\end{abstract}

KEY WORDS: ASSESSMENT, PURPOSE, SCHOOL CHILDREN, OBSERVATIONAL.

\section{INTRODUCTION}

Ametropia is a refractive error condition defined as a state of refraction when parallel rays of light coming from infinity are focused either in front or behind the retina after passing through the dioptric power of the eye when the accommodation is at rest. Globally, it is the most common cause of visual impairment and the second leading cause of treatable blindness. Early investigation and treatment can

Biosc Biotech Res Comm P-ISSN: 0974-6455 E-ISSN: 2321-4007

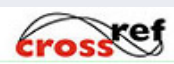

Identifiers and Pagination

Year: 2021 Vol: 14 No (7) Special Issue

Pages: $463-468$

This is an open access article under Creative

Commons License Attribn 4.0 Intl (CC-BY).

DOI: http://dx.doi.org/10.21786/bbrc/14.7.96 reduce the further deterioration and the risk of impaired vision. Vision impairment and blindness have been reported to cause loss of productivity and, as a result, economic instability, death, loss of earnings, and low quality of life worldwide. Uncorrected refractive defects can cause shortand long-term effects in adults and children, including loss of educational and employment possibilities for people, families, and society. It can also harm a child's classroom learning process. 19 million children are estimated to be visually impaired globally, with refractive errors accounting for 12 million nationally (Negrel, 2000; Dandona et al., 2001; Khurana et al., 2006; Mariotti, 2012; Bhoi et al., 2019; Wiryani et al., 2021).

Each of the RESC refractive error survey school) surveys was designed to investigate the age and sex-specific prevalence of refractive error and accompanying visual impairment in children of various ethnic origins and

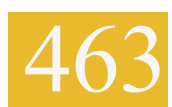


cultural situations. India has limited population-based refractive error data, with most coming from schoolchildren. Children are generally unaware of the problem and do not complain. This requires early detection and treatment of ocular morbidity and vision impairment. The blindness control program launched a school eye screening program in 1994. With Vision 2020-the right to sight, which set a goal of eliminating cataracts, xerophthalmia, and other preventable causes of juvenile blindness by 2020. India accounts for $20 \%$ ( 7.8 million) of the world's 39 million blind people, with cataracts accounting for $62 \%$, refractive error for $19.7 \%$, glaucoma for $5.8 \%$, and corneal blindness $1 \%$. According to Indian studies, refractive errors account for 81.7 percent of urban visual impairment (Limburg, 1995; Kalikivayi, 1997; Dandona, 1999; Negrel et al., 2000; Kawuma et al., 2002; Park et al., 2002; Ore et al., 2009; WHO et al., 2014; Wiryani et al., 2021).

Thus, the current study assesses the prevalence of various refractive errors among senior secondary school children in urban areas of district Etawah.

\section{MATERIAL AND METHODS}

Aim and Objective: The purpose of this study was to determine the prevalence of refractive error among senior secondary school students inurban communities at district Etawah.

Enrollment and ethical permission: A community-based cross-sectional study was done by randomly selected senior secondary school children from (9th-12th) standard of urban areas of district Etawah UP with the institutional ethical permission-NIMSUNI/IEC/2019/PhD/137.

Subject Recruitment: Informed and written Consent was obtained from the secondary school where the data is collected. All tests were given in front of a teacher during school hours on weekdays (Monday-Saturday). Male and female students from 9th to 12th grades present on the day of screening were chosen for the eye examination. Participants with dry eye, accommodative problems, amblyopia, squint, or other organic defects were excluded from the study.

The data was recorded on the Eye Exam Sheet (EES). To assess refractive error-related factors, the children were given a multilingual questionnaire. Snellen's Vision chart English optotype at 6 meters was used to test vision. Subjective assessment for the refractive error was done in either one or both eyes with $<6 / 12$ vision. the objective refraction was performed using a Retino scope under cycloplegic refraction (Tropicamide Eye-drops) whenever required, then subjective refraction also be done. A power change was advised for youngsters who already wore glasses. This is a refractive error in one or both eyes. if the refractive error in either (subjective/objective) is (+2.00D) in case of hypermetropia. The ICD 11 categorization of disorders and related health conditions was used to categorize the severity of the visual impairment (2018). Low Acuity less than 6/12 to 6/18; Moderate acuity less than 6/18-6/60; Severe acuity less than 6/60-3/60; and Blindness acuity less than $3 / 60$.
This study analyzes the prevalence of Ametropia in school children in urban areas of district Etawah. The baseline demoFigureic characteristics were analyzed for homogeneity by using Mann Whitney U test. The ocular complaints were expressed as mean and standard deviation. The type of refractive errors was scrutinized to determine the statistical difference among the group at $95 \%$ confidence level $(\mathrm{P}<0.05)$ using the chi-square test. Ametropia in the overall right and left eye was expressed in percentage. Data was symbolized using suitable tables and Figures. All data was entered into the computer using SPSS software version 16

\section{RESULTS AND DISCUSSION}

On analysis of Ametropia in school children in urban areas of district Etawah, the baseline characteristics of some of the data passed the homogeneity with a significant statistical difference. A total of 1161 children were screened. The difference in the proportion of males and females in the study was insignificant with a p-value of 0.38 , with most of the male $(50.9 \%)$ and $(49 \%)$ female participants from the urban areas (Figure-1). The age is calculated as median with a minimum value of (12), maximum (17) with the Median value of 15 with an interquartile range of 2.0.

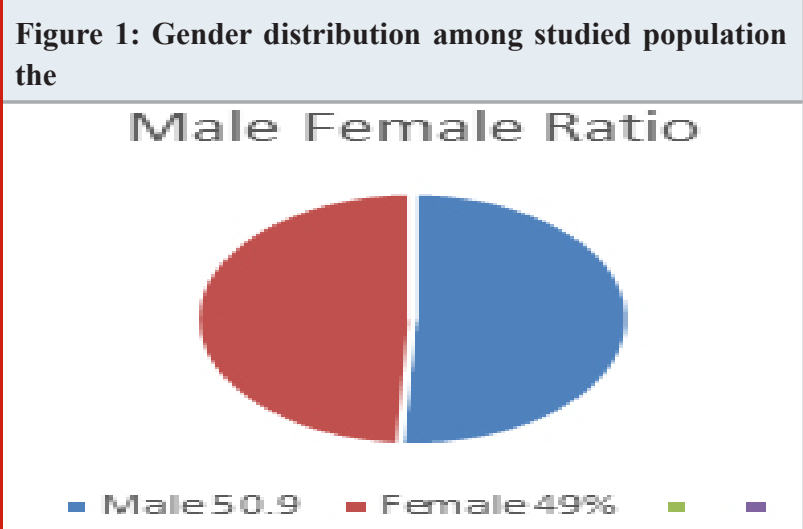

In the age group $<15$ years $(\mathrm{n}=1161)$, the female respondents account for $(55.1 \%)$ which is higher than male respondents $(44.8 \%)$. In order $\geq$ the15-year age group, the population distribution was higher among females $(52.2 \%)$ compared to male children's $(47.7 \%)$. The difference was statistically significant at $(\mathrm{p}<0.05)$. The Gender distribution of the examined population was not statistically significant from the enumerate population ( $\mathrm{n}=1161) ;(0.3843)$. Approximately three-fourths examined children were attending school, including almost all the younger ones but less than half of the 9th-year-old students. The difference was found to be insignificant in the 9th standard. (Table-1).

During Study and blur vision among the studied population, Headache was found to be statistically significant at $(\mathrm{p}<0.05)$ among gender comparison with age group. The results were not statistically significant at $(\mathrm{p}<0.05)$ for pain in the eye, Itching, eye pain during the study, eye discharge, Dryness, and Watering of eyes. 
Types of refractive error: The difference in the type of refractive error between Gender was found to be insignificant, with a p-value of 0.45 . Most female participants, $37(3.1 \%)$,reported myopia, followed by astigmatism in male children's $28(2.4 \%)$. Within the age group, the overall Ametropia was found to be more in $<15$ years of age, with the maximum number of cases reported in myopia 39(3.3\%) and least in hyper metropia 4(0.3\%) among schools of urban areas. The result was found to be statistically insignificant at $\mathrm{p}<0.05)$. (Table-3) Ametropia was found to be more in the right eye 97(8.4\%), with a higher prevalence reported in myopia in both eyes $(4.7 \%)$. Among school children's the least cases reported in both eyes was in hypermetropia $(0.7 \%)$ and $(0.8 \%)$. (Table- 4$)$.

Table 1. Baseline Demo Figureic Variables among Studied Population of Urban Areas ( $\mathrm{N}=1161)$ Ocular Complaints

\begin{tabular}{|c|c|c|c|c|c|}
\hline \multicolumn{3}{|c|}{ DemoFigureic Variables } & \multirow{3}{*}{$\begin{array}{c}\text { Z Score } \\
0.87\end{array}$} & \multirow{3}{*}{$\begin{array}{c}\text { P Value } \\
0.3843\end{array}$} & \multirow{3}{*}{$\begin{array}{c}\text { Significance } \\
\qquad P>0.05\end{array}$} \\
\hline Gender $(n=1161)$ & Male & $591(50.9)$ & & & \\
\hline & Female & $570(49.0)$ & & & \\
\hline \multirow[t]{3}{*}{ Age distribution } & $<15$ Year & $537(46.2)$ & -3.6109 & 0.0003 & \multirow[t]{3}{*}{$\mathrm{p}<.05$} \\
\hline & $\geq 15$ year & $624(53.7)$ & & & \\
\hline & $<15$ Year & $\geq 15$ year & & & \\
\hline Male & $265(44.8)$ & $272(47.7)$ & 20.92 & $<0.00001$ & $\mathrm{P}<0.05$ \\
\hline Female & $326(55.1)$ & $298(52.2)$ & 20.63 & $<0.00001$ & $\mathrm{P}<0.05$ \\
\hline Educational Level & Male & Female & & & \\
\hline $9^{\text {th }}$ class & $94(8.09)$ & $116(9.9)$ & -1.5918. & 0.11184 & $\mathrm{P}>0.05$ \\
\hline $10^{\text {th }}$ class & $177(15.2)$ & $129(11.1)$ & 2.9449 & .00328 & $\mathrm{P}<0.05$ \\
\hline $11^{\text {th }}$ class & $196(16.8)$ & $122(10.5)$ & 4.4668 & $<.00001$ & $\mathrm{p}<.05$ \\
\hline $12^{\text {th }}$ class & $124(10.6)$ & $203(17.4)$ & -4.7132 & $<.00001$ & $\mathrm{p}<.05$ \\
\hline
\end{tabular}

Table 2. Ocular complaints among the studied population in urban areas $n=1161$

\begin{tabular}{|l|c|c|c|c|c|}
\hline \multirow{2}{*}{ Ocular complaints } & \multicolumn{2}{|c|}{ Male } & \multicolumn{2}{c|}{ Female } & \multirow{2}{*}{ p-value } \\
\cline { 2 - 5 } & $\mathbf{1 5}$ Year & $\mathbf{1 5}$ year & $<\mathbf{1 5}$ Year & $\geq \mathbf{1 5}$ year & \\
Eye ache & $54 \pm 0.4$ & $54 \pm 0.3$ & $52 \pm 0.3$ & $65 \pm 0.4$ & \multirow{2}{*}{0.40} \\
\hline Headache during Study & $64 \pm 0.4$ & $61 \pm 0.3$ & $44 \pm 0.3$ & $78 \pm 0.4$ & 0.01 \\
\hline Blur Vision & $57 \pm 0.4$ & $111 \pm 0.3$ & $33 \pm 0.3$ & $109 \pm 0.4$ & 0.03 \\
\hline Eye Itching & $21 \pm 0.2$ & $44 \pm 0.3$ & $7 \pm 0.1$ & $15 \pm 0.2$ & 0.96 \\
\hline Pain in the eye during study & $48 \pm 0.3$ & $50 \pm 0.3$ & $35 \pm 0.3$ & $52 \pm 0.3$ & 0.23 \\
\hline Discharge from the eye & $1 \pm 0.06$ & $12 \pm 0.1$ & $4 \pm 0.1$ & $10 \pm 0.1$ & 0.16 \\
\hline Dryness in eyes & $13 \pm 0.2$ & $16 \pm 0.2$ & $21 \pm 0.2$ & $19 \pm 0.2$ & 0.52 \\
\hline Watering of the eye during study & $76 \pm 0.4$ & $88 \pm 0.4$ & $76 \pm 0.4$ & $97 \pm 0.4$ & 0.65 \\
\hline
\end{tabular}

Table 3. Comparison of types of Ametropia among school of urban areas. n-1161

\begin{tabular}{|c|c|c|c|c|c|c|c|}
\hline $\begin{array}{l}\text { VARIAB } \\
\text { LES }\end{array}$ & $\begin{array}{l}\text { OVERALL } \\
\text { AMETROPI } \\
\text { A }\end{array}$ & MYOPIA & $\begin{array}{l}\text { HYPERMETROP } \\
\text { IA }\end{array}$ & $\begin{array}{l}\text { ASTIGMATI } \\
\text { SM }\end{array}$ & $\begin{array}{l}\text { Chi } \\
\text { Square }\end{array}$ & $\begin{array}{l}\text { Signific } \\
\text { ance }\end{array}$ & $\begin{array}{l}\mathbf{P} \\
\text { Value }\end{array}$ \\
\hline \multicolumn{8}{|l|}{ Gender } \\
\hline MALE & $\begin{array}{l}56 \pm 0.2 \\
(4.8)\end{array}$ & $\begin{array}{l}33 \pm 0.2(2 . \\
8)\end{array}$ & $5 \pm 0.09(0.43)$ & $28 \pm 0.2(2.4)$ & \multirow[t]{2}{*}{2.61} & \multirow[t]{2}{*}{0.45} & \multirow[t]{2}{*}{$\begin{array}{l}\mathrm{p}>0.0 \\
5\end{array}$} \\
\hline $\begin{array}{l}\text { FEMAL } \\
\text { E }\end{array}$ & $54 \pm 0.2(4.6)$ & $\begin{array}{l}37 \pm 0.2(3 . \\
1)\end{array}$ & $5 \pm 0.09(0.43)$ & $17 \pm 0.1(1.4)$ & & & \\
\hline \multicolumn{8}{|l|}{ Age } \\
\hline$<15$ year & $\begin{array}{l}59 \pm 0.3 \\
(5.08)\end{array}$ & $\begin{array}{l}39 \pm 0.2(3 . \\
3)\end{array}$ & $4 \pm 0.08(0.3)$ & $26 \pm 0.2(2.2)$ & \multirow[t]{2}{*}{1.10} & \multirow[t]{2}{*}{0.77} & \multirow[t]{2}{*}{$\begin{array}{l}\mathrm{p}>0.0 \\
5\end{array}$} \\
\hline$\geq 15$ year & $\begin{array}{l}52 \pm 0.2(4.47 \\
)\end{array}$ & $\begin{array}{l}32 \pm 0.2(2 . \\
7)\end{array}$ & $6 \pm 0.09(0.08)$ & $19 \pm 0.1(1.6)$ & & & \\
\hline
\end{tabular}


Table 4. Estimation of Ametropia and its types covering both eyes

\begin{tabular}{|l|l|c|r|}
\hline Ametropia & Mean(\%) & Right Eye & Left Eye \\
\hline Overall Ametropia & $111(9.5)$ & $97(8.4)$ & $94(8.1)$ \\
\hline Myopia & $77(6.1)$ & $54(4.7)$ & $55(4.7)$ \\
\hline
\end{tabular}

Ametropia: In our study, the overall prevalence of refractive error $(\mathrm{n}=1161)$ in the urban areas was found to be $(9.5 \%)$ with most of the cases seen in male children $(4.8 \%)$. This is similar to the study done by Bhoi et al., (2019), (5.46\%). Khandekaret et al., (2009) In contrast, Triveni et al. (2021) reported a much higher prevalence of refractive error (47.37\%) in the age group of 9-12 years in the urban areas, which was much higher compared to our study. Studies reported that the estimation of refractive error increased with the increasing age and is most seen in the age group of 9-12 years among school children of urban areas. This might be due to the usage of displays, digital gadgets, working without prescribed glasses, from the proximity in the dim/very bright digital lights for the extended period to complete the projects and other educational activities among the urban areas. (Bataineh, 2008; Sharma, 2009; Rathod et al., 2011; Rathod, 2011; Kumar, 2014; Kumar, 2016; Vidusha, 2018; Saeed, 2021; Wiryani et al., 2021; Triveni et al., 2021).

Myopia: Among the types of Ametropia, the bulk of respondents had myopia (6.1\%), followed by $(3.8 \%)$ Astigmatism and $(0.8 \%)$ hyper metropia. Myopia was considered as the commonest type of refractive error reported in various studies conducted by Raju et al., (2004); Dandona (2002); Saw, (2008); Liang, (2009). Studies conducted by Vidhusha (2018); Shankar (2011) reported myopia as the most common pathology among refractive error. The study conducted by Dandona et. al (2002) reported myopia as a higher risk factor among the younger age group of urban areas due to variations in the literacy rates, lifestyle, educational demands. Uzma et al., (2009) Myopia was more prevalent in female children (3.1\%) than males, which is due to certain factors like after puberty, the growth and development of young females reach their peak. Wickham et al. confirmed it by the experimental study done on rats, rabbits, and human beings (Hashemi et al., 2018).

They found estrogen receptor (ER) mRNA expressions on the cornea, meibomian glands, retinal pigment epithelial cells. This study shows that the increased estrogen levels had a certain influence on cornea thickness, especially on the myopic diopter. Wickham et al., (2000) the other factor might include limited outdoor activity time than males. Myopia was seen more frequently in $<15$ years of age $(3.3 \%)$ among the urban areas in relation to the age group. Evidence suggests that the prevalence rate is higher $(16.2 \%)$ in china between the age group of 5 to 15 years, Zhao et al., (2000) (38.1\%) in Guangzhou He et al., (2004) and (36.7\%) in Hong Kong. Fan et al., (2004) among the same age groups. The variation among different countries and within India might be because of the disparities among lifestyle, ethnicity, and varied locations among the other age groups.

Hypermetropia: Some studies like Aine (1984), Onua (2012) Abdullah et al., (2015), and show hypermetropia as the commonest refractive error among the population. In our study, the prevalence was seen in $<15$ years with $(0.3 \%)$ urban areas.

Astigmatism: The prevalence rate of astigmatism in our study was seen in $<15(2.2 \%)$ years male $(2.4 \%)$. According to the United States survey on adults of $>20$ years of age groups, the prevalence rate was usually higher in above 60 years' male $(50.1 \%)$. This variation can be explained due to the differences in geo Figureical areas, race, ethnicity, etc. It can be suggested that astigmatism increases with increasing age (Vitale et al., 2008).

Right eye or left eye: In our study, it is also reported that the refractive error is mostly seen in the right eye of the patient with myopia $(4.7 \%)$, hypermetropia $(0.8 \%)$, and astigmatism $(3.0 \%)$ as compared with the left eye. Hypothetically this can be linked with the fact that about $90 \%$ of the population is right-handed, and of those, $67 \%$ are right eye dominate. The eye relays information more accurately to the brain's visual cortex for processing visual data from one eye to the other with more neural connections to the dominating eye. This fact might determine the eye's dominance, but no scientific evidence proved these findings.

\section{CONCLUSION}

Refractive errors (myopia) were more common in metropolitan schoolchildren. Refractive error was more common in urban school children aged 15 and under (especially females). Myopia was determined to be the most prevalent refractive error, followed by astigmatism and hyperopia. Preschool and school screenings should be conducted to detect refractive problems early. Furthermore, schoolchildren and their parents should be taught about refractive errors.

\section{REFERENCES}

Abdullah, A.S., Jadoon, M.Z., Akram, M., Awan, Z.H., Azam, M., Safdar, M. and Nigar, M., (2015). Prevalence of uncorrected refractive errors in adults aged 30 years and above in a rural population in Pakistan. Journal of Ayub Medical College Abbottabad, 27(1), pp.8-12.

Ağın, A., Kocabeyoglu, S., Gencoglu, A.Y., Aksoy, S., Karakaya, J. and Irkec, M., (2021). The effects of systemic aromatase inhibitors on meibomian glands and corneal structure. Eye, pp.1-9.

Ayub Ali, I.A. and Ayub, S., (2007). Prevalence of undetected refractive errors among school children. Biomedica, 23, pp.96-101.

Bataineh, H.A. and Khatatbeh, A.E., (2008). Prevalence of Refractive Errors in School Children (12-1 ears of afila Cit. Sudanese Journal of Public Health, 3(4).

Bhoi S, Mohapatra K, Subudhi BN, Ray P. (2019). Prevalence of refractive errors in rural population of 
Ganjam, Southern Odisha.J. Evid. Based Med. Healthc.; 6(42), 2773-2777. DOI: 10.18410/jebmh/2019/576.

Dandona, R. and Dandona, L., (2001). Refractive error blindness. Bulletin of the World Health Organization, 79, pp.237-243.

Dandona, R., Dandona, L., Naduvilath, T.J., Srinivas, M., McCarty, C.A. and Rao, G.N., (1999). Refractive errors in an urban population in southern India: the Andhra Pradesh Eye Disease Study. Investigative ophthalmology \& visual science, 40(12), pp.2810-2818.

Dandona, R., Dandona, L., Srinivas, M., Sahare, P., Narsaiah, S., Munoz, S.R., Pokharel, G.P. and Ellwein, L.B., (2002). Refractive error in children in a rural population in India. Investigative ophthalmology \& visual science, 43(3), pp.615-622.

Dandona, R., Dandona, L., Srinivas, M., Giridhar, P., McCarty, C.A. and Rao, G.N., (2002). Population $\square$ based assessment of refractive error in India: the Andhra Pradesh eye disease study. Clinical \& experimental ophthalmology, 30(2), pp.84-93.

Fan, D.S., Lam, D.S., Lam, R.F., Lau, J.T., Chong, K.S., Cheung, E.Y., Lai, R.Y. and Chew, S.J., (2004). Prevalence, incidence, and progression of myopia of school children in Hong Kong. Investigative ophthalmology \& visual science, 45(4), pp.1071-1075.

Hashemi, H., Nabovati, P., Yekta, A., Shokrollahzadeh, F. and Khabazkhoob, M., (2018). The prevalence of refractive errors among adult rural populations in Iran. Clinical and Experimental Optometry, 101(1), pp.84-89.

He, M., Zeng, J., Liu, Y., Xu, J., Pokharel, G.P. and Ellwein, L.B., (2004). Refractive error and visual impairment in urban children in southern China. Investigative ophthalmology \& visual science, 45(3), pp.793-799.

Kalikivayi, V., Naduvilath, T.J., Bansal, A.K. and Dandona, L., (1997). Visual impairment in school children in Southern India. Indian journal of ophthalmology, 45(2), p.129.

Kawuma, M. and Mayeku, R., (2002). A survey of the prevalence of refractive errors among children in lower primary schools in Kampala district. African health sciences, 2(2), pp.69-72.

Kempen, J.H., Mitchell, P., Lee, K.E., Tielsch, J.M., Broman, A.T., Taylor, H.R., Ikram, M.K., Congdon, N.G. and O'Colmain, B.J., (2004). The prevalence of refractive errors among adults in the United States, Western Europe, and Australia. Archives of ophthalmology (Chicago, Ill.: 1960), 122(4), pp.495-505.

Kumar, P., Pore, P., Dixit, A.K. and Singh, N., (2014). Prevalence and demoFigureic distribution of refractory error in school children of Pune, India. Int J Res Health Sci, 2(1), pp.58-67.

Kumar, K.S. and Akoijam, B.S., (2016). Prevalence of refractive error among school-going children of Imphal,
Manipur. Int J Med Sci Public Health, 5, pp.1364-1368. Limburg, H., Vaidyanathan, K. and Dalal, H.P., (1995). Cost-effective screening of schoolchildren for refractive errors. In World health forum 1995; 16 (2): 173-178.

Liang, Y.B., Wong, T.Y., Sun, L.P., Tao, Q.S., Wang, J.J., Yang, X.H., Xiong, Y., Wang, N.L. and Friedman, D.S., (2009). Refractive errors in a rural Chinese adult population: the Handan eye study. Ophthalmology, 116(11), pp.2119-2127.

Mabaso, R.G. and Oduntan, O.A., (2014). Prevalence and causes of visual impairment and blindness among adults with diabetes mellitus aged 40 years and older receiving treatment at government health facilities in the Mopani District, South Africa. African Vision and Eye Health, 73(1), pp.8-15.

Negrel, A.D., Maul, E., Pokharel, G.P., Zhao, J. and Ellwein, L.B., (2000). Refractive error study in children: sampling and measurement methods for a multi-country survey. American journal of ophthalmology, 129(4), pp.421-426.

Onua, A.A., Pedro-Egbe, C.N. and Babatunde, S., (2012). Prevalence of refractive error in a rural Ogoni community in Southern Nigeria. Nigerian Journal of Ophthalmology, 20(1), pp.30-32.

Ore, L., Garzozi, H.J., Tamir, A. and Cohen-Dar, M., (2009). Vision screening among northern Israeli Jewish and Arab schoolchildren. The Israel Medical Association journal: IMAJ, 11(3), pp.160-165.

Park, K.J.F., (2002). Park. Park's Text book of Preventive Social Medicine.

Padhye, A.S., Khandekar, R., Dharmadhikari, S., Dole, K., Gogate, P. and Deshpande, M., (2009). Prevalence of uncorrected refractive error and other eye problems among urban and rural school children. Middle East African journal of ophthalmology, 16(2), p.69.

Pokharel, G.P., Negrel, A.D., Munoz, S.R. and Ellwein, L.B., (2000). Refractive error study in children: results from Mechi Zone, Nepal. American journal of ophthalmology, 129(4), pp.436-444.

Raju, P., Ramesh, S.V., Arvind, H., George, R., Baskaran, M., Paul, P.G., Kumaramanickavel, G., McCarty, C. and Vijaya, L., (2004). Prevalence of refractive errors in a rural South Indian population. Investigative ophthalmology \& visual science, 45(12), pp.4268-4272.

Rathod HK, Raghav PR, Mittal S. (2011) Profile of School Going Children with Visual Impairment. Ind Med Gaz. 116(7)434-7.

Saw, S.M., Chan, Y.H., Wong, W.L., Shankar, A., Sandar, M., Aung, T., Tan, D.T., Mitchell, P. and Wong, T.Y., (2008). Prevalence and risk factors for refractive errors in the Singapore Malay Eye Survey. Ophthalmology, 115(10), pp.1713-1719.

Saeed, A. (2021). Knowledge, attitudes, and beliefs of 
newly enrolled undergraduate students towards refractive corrections-A questionnaire-based study. Psychology and Education Journal, 58(4), 1125-1138.

Shakeel, T. and Mittal, S.K., (2016). Pattern of refractive errors in primary school children in Dehradun city of Uttrakhand State. The Official Scientific Journal of Delhi Ophthalmological Society, 27(2), pp.106-110.

Sharma S, Bashisth BM, Kalhan M GM. (2009). Ocular infection in school children in a rural block of Haryana. Int J Epidimiol.6(2). pp. 21-28

Shrestha, G.S., Sujakhu, D. and Joshi, P., (2011). Refractive error among school children in Jhapa, Nepal. Journal of optometry, 4(2), pp.49-55.

Triveni C, Divya T, Rama Devi P, Chowdary N, Sirisha G. (2021). Prevalence of Refractive Errors in School Going Children in rural and urban areas -A Cross-Sectional Study. Tropical Journal of Ophthalmology and Otolaryngology. 6(2): 22-26.

Uzma, N., Kumar, B.S., Salar, B.K.M., Zafar, M.A. and Reddy, V.D., (2009). A comparative clinical survey of the prevalence of refractive errors and eye diseases in urban and rural school children. Canadian journal of ophthalmology, 44(3), pp.328-333.

Vidusha, K.S.S. and Damayanthi, M.N., (2018). Prevalence of refractive errors among school children in the rural field practice area of a tertiary care hospital, Bengaluru. Int J Community Med Public Health, 5(4), pp.1471-1476.

Vidusha, K.S.S. and Damayanthi, M.N., (2018). Prevalence of refractive errors among school children in the rural field practice area of a tertiary care hospital, Bengaluru. Int J Community Med Public Health, 5(4), pp.1471-1476.

Wickham, L.A., Gao, J., Toda, I., Rocha, E.M., Ono, M. and Sullivan, D.A., (2000). Identification of androgen, estrogen and progesterone receptor mRNAs in the eye. Acta Ophthalmologica Scandinavica, 78(2), pp.146-153. Wiryani, F., Setiawan, Y. I. S., Nasser, M., \& Najih, M. (2021). Disclosure of medical secrets in handling corona virus disease (Covid)-19 cases. Indian Journal of Forensic Medicine \& Technology, 15(3).

Zhao, J., Pan, X., Sui, R., Munoz, S.R., Sperduto, R.D. and Ellwein, L.B., (2000). Refractive error study in children: results from Shunyi District, China. American journal of ophthalmology, 129(4), pp.427-435. 